Discussion Paper No. 08-129

Do Older Workers Lower IT-Enabled Productivity?

Firm-Level Evidence from Germany

Irene Bertschek and Jenny Meyer

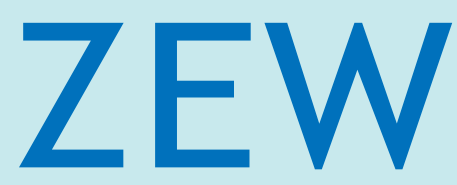

Zentrum für Europäische Wirtschaftsforschung $\mathrm{GmbH}$

Centre for European

Economic Research 


\section{Discussion Paper No. 08-129 \\ Do Older Workers Lower IT-Enabled Productivity? Firm-Level Evidence from Germany}

Irene Bertschek and Jenny Meyer

Download this ZEW Discussion Paper from our ftp server:

ftp://ftp.zew.de/pub/zew-docs/dp/dp08129.pdf

Die Discussion Papers dienen einer möglichst schnellen Verbreitung von neueren Forschungsarbeiten des ZEW. Die Beiträge liegen in alleiniger Verantwortung der Autoren und stellen nicht notwendigerweise die Meinung des ZEW dar.

Discussion Papers are intended to make results of ZEW research promptly available to other economists in order to encourage discussion and suggestions for revisions. The authors are solely responsible for the contents which do not necessarily represent the opinion of the ZEW. 


\section{Non-Technical Summary}

The role of information and communication technologies (ICT) as a driving force for productivity and competitiveness is in the meanwhile well recognized. A look at the country level, however, reveals that the contribution of ICT capital to GDP growth, although still positive, has diminished considerably during the period between 2000 and 2005, compared to the period between 1995 and 2000, in almost all OECD countries. During the same time period the labour force participation of older people has increased owing to demographic changes.

This paper provides empirical evidence on the question whether firms' IT-enabled labour productivity is affected by the age structure of the workforce. Therefore, we take a micro-perspective by analysing firm-level data from German manufacturing and services industries. We find that workers older than 49 are not significantly less productive than prime age workers between 30 and 49, whereas workers younger than 30 are significantly less productive than prime age workers. Older workers using a computer are significantly more productive than older non-computer users. Moreover, we find that the significantly positive relationship between labour productivity and IT intensity is not affected by the proportion of older workers.

In a further step, we take account of the fact that companies might employ only the best or most productive older workers while less productive employees leave the labour market either actively or passively via early retirement programmes, for instance. However, the previously found result that the percentage of older workers is not significantly related to labour productivity is supported. 


\section{Zusammenfassung}

Die Bedeutung von Informations- und Kommunikationstechnologien (IKT) als Triebfeder für Produktivität und Wettbewerbsfähigkeit ist mittlerweile unumstritten. Ein Blick auf die Makroebene zeigt, dass der Beitrag von IKT zum Wachstum des Bruttoinlandsprodukts im Zeitraum von 2000 bis 2005 zwar immer noch positiv ist, jedoch im Vergleich zum Zeitraum 1995 bis 2000 in fast allen OECD-Ländern deutlich abgenommen hat. Dagegen ist die Arbeitsmarktpartizipation Älterer zwischen 2000 und 2005, nicht zuletzt aufgrund der demografischen Entwicklung, deutlich gestiegen.

Im vorliegenden Papier gehen wir der Fragestellung nach, ob eine alternde Belegschaft mit der effizienten Nutzung von IKT in Konflikt steht. Hierzu nehmen wir eine Mikroperspektive ein und untersuchen Unternehmensdaten aus dem verarbeitenden Gewerbe und aus Dienstleistungssektoren in Deutschland.

Die Ergebnisse zeigen, dass ältere Beschäftigte ab 50 nicht weniger produktiv sind als ihre jüngeren 30- bis 49-jährigen Kollegen. Dagegen weisen Beschäftigte, die jünger als 30 sind, eine signifikant geringere Produktivität auf als die 30- bis 49Jährigen. Ältere Computernutzer erweisen sich als signifikant produktiver als ältere Nicht-Computernutzer. Des Weiteren finden wir, dass der positive und signifikante Zusammenhang zwischen der Arbeitsproduktivität und der IT-Intensität der Unternehmen nicht vom Anteil älterer Beschäftigter beeinträchtigt wird.

In einem weiteren Schritt berücksichtigen wir, dass ein Unternehmen nur die produktivsten älteren Mitarbeiter beschäftigen könnte, während weniger produktive das Unternehmen und den Arbeitsmarkt aktiv oder passiv, beispielsweise mittels Frühverrentung, vorzeitig verlassen. Diese Analysen bestätigen die zuvor gefundenen Ergebnisse, dass ältere Mitarbeiter die Arbeitsproduktivität auf Unternehmensebene nicht beeinträchtigen. 


\title{
Do Older Workers Lower IT-Enabled Productivity? Firm-Level Evidence from Germanys
}

\author{
IRENE BERTSCHEK * \\ JENNY MEYER
}

December 2008

\begin{abstract}
The paper provides empirical evidence for the question whether firms' ITenabled labour productivity is affected by the age structure of the workforce. We apply a production function approach with heterogenous labour to firmlevel data from German manufacturing and services industries. We find that workers older than 49 are not significantly less productive than prime age workers, whereas workers younger than 30 are significantly less productive than prime age workers. Older workers using a computer are significantly more productive than older non-computer users. The positive and significant relationship between labour productivity and IT intensity is not affected by the proportion of older workers.
\end{abstract}

JEL-classification: J14, J24, O33

Keywords: labour productivity, information technology, older workers

\footnotetext{
$\S$ Acknowledgement: The research is part of the project "Explaining Productivity Growth in Europe, America and Asia" funded by the Anglo-German Foundation. We thank Ulrich Kaiser, Marianne Saam, Michael Ward and Thomas Zwick as well as the participants of the CSGE midpoint meeting for helpful comments.

*ZEW, ICT Research Group, P.O. Box 103443, D-68034 Mannheim, email: bertschek@zew.de.

†ZEW, ICT Research Group, P.O. Box 103443, D-68034 Mannheim, email: meyer@zew.de.
} 


\section{Introduction}

According to the Lisbon Agenda, the strategic goal for the European Union is "...to become the most competitive and dynamic knowledge-based economy in the world, capable of sustainable economic growth with more and better jobs and greater social cohesion" (Lisbon European Council, 2000). As general purpose technologies (Bresnahan and Trajtenberg, 1995) information and communication technologies (ICT) have been recognised as a key technology for competitiveness. They have diffused to firms and workplaces of all sectors during the last decades giving rise to the so-called knowledge-based economy. About 58 percent of the employees in Germany currently use a computer at their workplace on a regular basis compared to 46 percent in 2002 (Statistisches Bundesamt, 2007). Various empirical evidence shows that the use of ICT enhances firm productivity, in particular if ICT usage is complemented by appropriate organisational measures 1 . A look at the country level, however, reveals that the contribution of ICT capital to GDP growth, although still positive, has diminished considerably during the period between 2000 and 2005 compared to the period between 1995 and 2000 in almost all OECD countries ${ }^{2}$

A further major trend in industrialised countries is marked by an increase in life expectancy and a simultaneous decrease in birthrates, leading to an enormous pressure on the social security systems. The target set up by the Stockholm Council in March 2001 is to raise the employment rate of seniors in the European Union (i.e. people aged 55 to 64 years) to $50 \%$ by 2010 . In the EU-25, the labour force participation of older people has increased by 5.9 percentage points from 2000 to 2005, reaching a level of $42.5 \%$. In Germany, this increase was above average with 7.5 percentage points and a level of $44.9 \%$ in 2005 (Aliaga and Romans, 2006) $!^{3}$ This development represents a great challenge for firms. High productivity is an important objective in order to stay competitive in an economy that is characterised by rapid technological progress. Does an ageing workforce conflict with this objective?

This paper provides empirical evidence on the question whether firms' IT-enabled labour productivity is affected by the age structure of the workforce. Therefore, we

\footnotetext{
${ }^{1}$ A recent survey of the literature is given by Draca, Sadun and van Reenen (2007).

${ }^{2}$ See the OECD productivity data base, 2006.

${ }^{3}$ Several countries of the European Union have already passed the goal of $50 \%$. In Sweden, for example, nearly $70 \%$ of the people aged between 55 and 64 years participated in the labour market in the year 2005 and in Denmark the average labour force participation rate of this age group was about $60 \%$ in 2005 (see Aliaga and Romans, 2006).
} 
apply a production function approach with heterogenous labour to a firm-level data set from the German manufacturing and services industries. It comprises data from 1039 firms observed in the years 2004 and 2007.

We find that employees aged younger than 30 years are significantly less productive than prime age employees, whereas employees being older than 49 do not differ significantly from prime age employees between 30 and 49. Older computer users are significantly more productive than older non-computer users. The significantly positive relationship between labour productivity and IT intensity is not affected by the proportion of older employees implying that older employees do not lower IT-enabled productivity.

The paper is structured as follows: The next section gives an overview about the background discussion in economic literature. Section three presents some theoretical considerations and the empirical model. The data used for the empirical analyses is presented and described in section four. In section five the results are presented and discussed. Section six concludes.

\section{Background Discussion}

The topic of this paper is related to various strands of the literature. First, there is the literature about the productivity effects of ICT. Recent firm-level studies all find a positive and significant relationship between productivity and ICT with ICT being generally measured by ICT capital or ICT investment 4 Moreover, these studies claim that ICT has to be accompanied by appropriate organisational measures in order to fully exploit the productivity gains. Therefore, ICT investment and organisational investment are interpreted as strategic complements.5

A further strand of literature deals with the so-called age-biased technological change. It analyses whether older workers have age-related disadvantages in using new technologies compared to younger workers. Some studies focus on the relationship be-

\footnotetext{
${ }^{4}$ See for instance the overviews by Bertschek (2003), Brynjolfsson and Hitt (2000) and Draca et al. (2007).

${ }^{5}$ This discussion is mainly related to decentralising organisational measures implying a greater involvement of employees in decision-making processes and more responsibilities of employees. Some examples are team work, flat hierarchies, autonomous working groups or incentive pay. See for instance Black and Lynch (2001), Brynjolfsson and Hitt (2000), Bresnahan, Brynjolfsson and Hitt (2002), and Bertschek and Kaiser (2004).
} 
tween the use of ICT and the employment of elderly persons at the firm level ${ }^{6}$

As Bartel and Sichermann (1993) point out, technological change impacts the retirement decision of older workers in two different ways: On the one hand, it directly affects retirement decisions by enforcing training and thus gives incentives to stay on the job. On the other hand, technological change - when it arises unexpectedly accelerates the depreciation of human capital and thus makes training less attractive in particular for older employees, who then may prefer to retire earlier (Bartel and Sichermann, 1993). The empirical study by Friedberg (2003) points in the same direction. Using two data sets from the U.S. she finds that computer users tend to retire later than non-users because they probably have comparative advantages and are ready to invest in training. However, the readiness to invest in training is negatively correlated with impeding retirement. Taking into account more detailed information on employees' individual characteristics reveals that it is not the age that is decisive for the use or non-use of ICT, it is rather occupation, education and skills that determine the use of ICT (Borghans and ter Weel, 2002; Friedberg, 2003; Hirsch, MacPherson and Hardy, 2000; Schleife, 2006; Weinberg, 2004). The use of new technologies generally increases skill requirements - a topic which is extensively discussed in the skill-biased technological change literature.7

Taking into account the complementary relationship between ICT and organisational factors, some empirical studies also consider workplace practices to explain the age structure of the workforce at the firm level (Aubert, Caroli and Roger, 2006; Beckmann, 2001; Bertschek, 2004). They find that innovative workplace practices giving more decision-making authority and responsibility to employees is negatively related to the employment of older workers.

The third and last strand of literature which is relevant to our paper deals with the productivity of older workers. From a gerontological point of view, the fluid part of the brainpower - the part which is responsible for efficiently processing information and for adapting to new situations - decreases with age. By contrast, the cristalline intelligence comprising verbal competence and experience rather increases with age. As Börsch-Supan, Düzgün and Weiss (2005) point out, it is not only the individual productivity that matters. The working environment of employees such as the age

\footnotetext{
${ }^{6}$ For empirical evidence for Germany, see for example Bertschek (2004) and Boockmann and Zwick (2004).

${ }^{7}$ See for example the overview articles by Chennells and van Reenen (2002) and Card and DiNardo (2002). For an analysis of changing skill requirements owing to the diffusion of IT see Autor, Levy and Murnane (2003) and Spitz-Oener (2006).
} 
structure of a team, the workplace organisation and the spread of lifelong learning opportunities are more important.

There are many economic and empirical studies on the relationship between age and productivity (see the surveys by Börsch-Supan et al., 2005, and by Skirbekk, 2004). Firm-level studies usually measure firm-level productivity by sales or by the value added per employee. Studies at the individual level focus on wages as an individual measure of productivity. Analyses based on linked employer-employee data combine the two approaches. Most econometric studies find a hump shaped age-productivity profile implying a relatively high productivity for prime age workers (aged between 30 and 50 or between 35 and 55) and lower productivities for younger and older workers 8 Some authors highlight the importance of employees' formal qualification (Haltiwanger et al.,1999, Hellerstein et al., 1999, Crépon et al., 2002) as well as the importance of experience aquired in the firm (Ilmakunnas et al., 2004).

To the best of our knowledge, there is no study which relates firm productivity to the use of ICT and to the age structure of employees. On the one hand, the productivity studies that focus on the effects of the age structure of employees do not consider ICT as a further production factor. On the other hand, studies that find empirical evidence for positive productivity effects of ICT at the firm level do not consider the age structure of the workforce. Our paper attempts to close this gap by considering both ICT and the age structure of the workforce using two waves of a firm-level data set.

\footnotetext{
${ }^{8}$ To cite some examples, Crépon, Deniau and Pérez-Duarte (2002) use French linked employeremployee data and find the highest productivity for prime age workers who are aged between 25 and 34 years old. Haltiwanger, Lane and Spletzer (1999) provide evidence using a U.S. longitudinal linked employer-employee data set. They find a lower productivity of employees older than 55. The age group between 30 and 49 turns out to be the most productive. However, the age structure of the workforce does not play a role for changes in productivity over time. For the case of Germany Schneider (2007), using linked employer-employee data, also finds a hump shaped age-productivity profile. There is evidence for Denmark (Grund and Westergard-Nielsen, 2005), Finland (Ilmakunnas, Maliranta and Vainiomki, 2004), Sweden (Prskawetz, Mahlberg, Skirbekk, Freund, Winkler-Dworak, Lindh, Malmberg, Jans, Nordström and Andersson, 2006), as well as further evidence for France (Aubert and Crépon, 2003) and the U.S. (Hellerstein, Neumark and Troske, 1999).
} 


\section{Analytical Framework}

The basis of our simplified analytical framework is a Cobb-Douglas production function with various input factors:

$$
Y_{i}=f\left(A_{i}, L_{i}^{*}, K_{i}, W O_{i}, \text { controls }\right)
$$

The output $Y_{i}$ of firm $i$ depends on the input factors labour, $L_{i}^{*}$, capital, $K_{i}$ and workplace organisation $W O_{i}$. The parameter $A_{i}$ measures total factor productivity and reflects the efficiency of production. Controls comprise industry, region and firms' export activity.

The labour parameter $L_{i}^{*}$ represents the aggregated efficiency units of labour. It consists of $k$ different types $L_{i}^{k}$ of employees working with different productivities:

$$
L_{i}^{*}=g\left(L_{i}^{q u a l}, L_{i}^{a g e}, L_{i}^{P C}\right)
$$

where $L_{i}^{\text {qual }}$ represents labour heterogeneity according to qualification, $L_{i}^{\text {age }}$ represents the age structure of employees, and $L_{i}^{P C}$ takes into account the share of employees working on a computer 9

More formal versions of this framework and a discussion of the underlying assumptions can be found in Hellerstein et al. (1999), Crépon et al. (2002) and Schneider (2007).

In the econometric estimations labour productivity measured by the logarithm of sales per employee is used as dependent variable:

$$
\ln \left(\frac{Y_{i}}{L_{i}}\right)=f\left(\ln A_{i}, \ln L_{i}, \ln K_{i}, L_{i}^{q u a l}, L_{i}^{a g e}, L_{i}^{P C}, W O_{i}, \text { controls }\right)
$$

As input factors we consider labour, capital, the workforce's qualification and age structure, employees working on computers and workplace organisation. We expect that labour productivity is positively related to high- and medium-skilled employees, to employees working at computers and to high performance workplace practices. Younger and older employees are expected to be less productive than the reference

\footnotetext{
${ }^{9}$ Instead of interpreting the share of employees using computers at the workplace as a factor of labour heterogeneity, it might alternatively be interpreted as a measure of IT capital.
} 
group of prime age employees. According to previous research results presented in the background discussions, we also hypothesise that there are complementarities between IT intensity and workplace organisation. Additionally, we expect that older employees negatively interact with IT intensity and workplace organisation. The following section describes the measures of the variables as used in the estimations.

\section{Data Description}

The firm-level data used for the empirical analyses result from the ICT survey of the Centre for European Economic Research (ZEW) and was collected in 2004 and 2007. Each year 4.400 firms were surveyed. The data are stratified according to industries (seven branches of the manufacturing industry and seven selected service sectors), to three size classes and to two regions (East/West Germany). The data are constructed as a panel, therefore the waves of 2004 and 2007 are merged in order to use information that is only contained in the wave of 2004. ${ }^{10}$ Considering item non-response for the age variables, there remains a sample of 1039 firms.

Labour productivity is measured as the log of (total annual sales)/(total no. of employees) and is used as the output variable. The input factor labour is measured by the logarithmised number of employees, which represents at the same time firm size. Capital stock is approximated by the log of gross investment.11

The following variables take account of the heterogeneity of labour as put forward by the theoretical considerations:

QUALIFICATION: The qualification of the employees is presented by the proportion of employees being high-skilled (degree from university, university of applied sciences or university of cooperative education) and medium-skilled (master craftsman, engineer or vocational training), respectively. The reference category is the proportion of low-skilled workers (without formal qualification).

\footnotetext{
${ }^{10}$ Due to the fact that not all variables are contained in both waves, panel estimations cannot be provided.

${ }^{11}$ Capital stock could potentially be approximated by applying the perpetual inventory method. However, there are not enough waves available for this purpose. Moreover, there is no information about value added and material input. The latter might be particularly important for manufacturing firms. These measurement problems might bias the estimates of the corresponding parameters. Nevertheless, it is not unusual to use gross investment as a proxy for capital and to use sales and not value added as a performance measure, see for example Griffith, Huergo, Mairesse and Peters (2006).
} 
$A G E$ : The share of workers aged 50 or older and the share of workers aged younger than 30 reflect the age structure of the workforce. So-called prime age workers between 30 and 49 are the reference group.

PCWORK: The share of workers predominately working at a $\mathrm{PC}$ measures the workers' technological skills and at the same time it reflects the companies' IT intensity.

OLD PCWORK: The share of older workers (older than 49) predominately working at a $\mathrm{PC}$.

WORKPLACE ORGANISATION: The dummy variables incentive wages and teams with profit and loss responsibility are measures of workplace organisation.

CONTROLS: A dummy variable accounts for firms' exporting activities. A dummy for East Germany takes account of the fact that East German firms are generally less productive than West German firms. Sector dummies control for sector-specific variation in labour productivity ${ }^{12}$

The variables measuring workplace organisation, old pcwork, and the dummy variable accounting for export activity refer to the survey of 2004, all other variables are taken from the survey of 2007. Table 1 shows some descriptive statistics of the variables for the total sample if observations with item non-response for all used variables are dropped.

Table 1: Descriptive Statistics: Total Sample

\begin{tabular}{lcccc}
\hline \hline \multicolumn{1}{c}{ Variable } & Mean & Std. Dev. & Min. & Max. \\
\hline labour productivity & 158594 & 131779 & 5147 & 800000 \\
firm size (no of emp.) & 138 & 301 & 5 & 4100 \\
gross investment & 1402506 & 3773259 & 1000 & 40000000 \\
share of empl. below 30 years & 0.252 & 0.172 & 0 & 0.9 \\
share of empl. above 49 years & 0.212 & 0.147 & 0 & 0.9 \\
share of high-skilled empl. & 0.216 & 0.248 & 0 & 1 \\
share of medium-skilled empl. & 0.593 & 0.252 & 0 & 1 \\
pcwork & 0.484 & 0.336 & 0 & 1 \\
old pcwork & 0.321 & 0.381 & 0 & 1 \\
incentive wages (dummy) & 0.555 & 0.497 & 0 & 1 \\
units with P\&L responsibility (dummy) & 0.36 & 0.48 & 0 & 1 \\
exporting activities (dummy) & 0.528 & 0.5 & 0 & 1 \\
\hline \multicolumn{1}{c}{$\mathrm{N}$} & \multicolumn{5}{c}{776} \\
\hline \hline
\end{tabular}

\footnotetext{
${ }^{12}$ The distribution of firms across sectors can be found in Table 4 in the appendix.
} 
Table 1 reveals that the labour productivity is 158,594 Euro per employee on average. The average firm size in the sample is about 138 employees. On average, the firms of the sample have a gross investment of about 1.4 million Euros. The share of employees being younger than 30 years is about 25 percent, whereas the share of employees aged 50 years or older is about 21 percent. The major share of employees is medium-skilled (about 59 percent). On average, 22 percent of the employees of the firms in the sample are high-skilled. About half of the staff works predominantly at a computer, whereas this share is lower amongst the older employees. On average, 32 percent of the employees being 50 years or older are working mainly at a computer. As for human resource practices, more than half of the firms use incentive wages, whereas only about 36 percent of the firms in the sample have units with profit and loss responsibility.

\section{Empirical Results}

The results of the OLS estimations are depicted in Tables 2 and 3 . Specification (1) shows the raw effects of the age groups. It implies that workers younger than 30 and workers older than 49 are less productive than prime age workers - a result that corresponds to the theoretical considerations. This result changes when sector dummies and a dummy for regional disparities are introduced (specification (2)). In this case, the share of older workers becomes insignificant whereas the coefficient of younger workers remains negatively significant.

Specification (3) additionally contains the input factors as well as further control variables. The input factors show the expected signs and coefficients. ${ }^{13}$

IT intensity measured by the proportion of employees working predominately at a computer is also positively significant reflecting the positive relationship between productivity and ICT that is also found in several other micro and macro studies. Moreover, high-skilled and medium-skilled employees are more productive than low-skilled employees. The human resource measures incentive wages and units with profit and loss responsibility are positively associated with labour productivity. Exporting firms are more productive than non-exporting firms 14

\footnotetext{
${ }^{13}$ The coefficient of labour is negative since it reflects the production elasticity of labour minus one. The estimated coefficients of the various categories of labour plus one reflect the productivity of the respective labour category relative to its reference group. For example, the relative produc-
} 
Table 2: Estimation Results, OLS

\begin{tabular}{|c|c|c|c|c|}
\hline \multicolumn{5}{|c|}{ dependent variable: log labour productivity } \\
\hline Variable & $(1)$ & (2) & (3) & (4) \\
\hline \multirow[t]{2}{*}{ share of empl. below 30 years } & $-0.259^{*}$ & $-0.256^{* *}$ & $-0.379^{* * *}$ & $-0.376^{* * *}$ \\
\hline & $(0.138)$ & $(0.128)$ & $(0.123)$ & $(0.126)$ \\
\hline \multirow{2}{*}{ share of empl. above 49 years } & $-0.352^{* *}$ & -0.259 & -0.075 & -0.184 \\
\hline & $(0.175)$ & $(0.168)$ & $(0.163)$ & $(0.165)$ \\
\hline \multirow[t]{2}{*}{$\log$ (employment) } & & & $-0.105^{* * *}$ & $-0.118^{* * *}$ \\
\hline & & & $(0.025)$ & $(0.025)$ \\
\hline \multirow[t]{2}{*}{ log (gross investment) } & & & $0.133^{* * *}$ & $0.144^{* * *}$ \\
\hline & & & $(0.019)$ & $(0.019)$ \\
\hline \multirow{2}{*}{ share of high-skilled empl. } & & & $0.501^{* * *}$ & $0.408^{* *}$ \\
\hline & & & $(0.162)$ & $(0.163)$ \\
\hline \multirow[t]{2}{*}{ share of medium-skilled empl. } & & & $0.354^{* * *}$ & $0.275^{* *}$ \\
\hline & & & $(0.118)$ & $(0.118)$ \\
\hline \multirow{2}{*}{ pcwork } & & & $0.451^{* * *}$ & $0.436^{* * *}$ \\
\hline & & & $(0.101)$ & $(0.101)$ \\
\hline \multirow[t]{2}{*}{ incentive wages } & & & $0.124^{* * *}$ & $0.118^{* * *}$ \\
\hline & & & $(0.045)$ & $(0.045)$ \\
\hline \multirow{2}{*}{ units with P\&L responsibility } & & & $0.108^{* *}$ & $0.094^{*}$ \\
\hline & & & $(0.049)$ & $(0.050)$ \\
\hline \multirow[t]{2}{*}{ exporting activities } & & & $0.101^{* *}$ & $0.087^{*}$ \\
\hline & & & $(0.047)$ & $(0.047)$ \\
\hline \multirow[t]{2}{*}{ old pcwork } & & & & $0.124^{* *}$ \\
\hline & & & & $(0.062)$ \\
\hline dummies for sectors and region & no & yes & yes & yes \\
\hline number of obs & 1039 & 1039 & 808 & 776 \\
\hline $\mathrm{R}^{2}$ & 0.006 & 0.184 & 0.365 & 0.375 \\
\hline F statistic & 3.15 & 19.37 & 20.58 & 20.73 \\
\hline
\end{tabular}

A further estimation considers the proportion of older employees working at a computer (specification (4) of Table 2). It has a positive and significant coefficient implying that older workers using a computer are more productive than older workers not using a computer. This result is in line with previous results from the skill-biased technological change literature showing that computer users are more productive than non-users, not because they use computers but because they are better qualified for using a computer.

\footnotetext{
tivity of employees working on computers according to specification (3) in Table 2 is $0.451+1$.

${ }^{14}$ This is in line with several studies for instance by Bernard and Jensen (2004). These studies all find a positive relationship between productivity and exports.
} 
Interaction effects between age groups and IT intensity are taken into account in specification (5) of Table 3. The estimated coefficient is negative in case of the interaction term between younger workers and IT usage whereas it is positive in case of the interaction between older workers and IT usage hinting at complementarities between experience and technology. However, both coefficients are insignificant. Thus, the positive and significant marginal effect of IT usage on firms' labour productivity is not affected by the percentage of older workers. The coefficient of the proportion of employees being younger than 30 years becomes insignificant.

As motivated in section 2, specifications (6) and (7) of Table 3 contain interaction terms between age groups and workplace practices and between IT intensity and workplace practices. However, these interaction terms are all insignificant. Moreover, the dummy variables presenting the use of units with own profit and loss responsibility turn to be insignificant as well.

Finally, specification (8) of Table 3 combines specifications (5), (6) and (7). The results do not change significantly. The coefficient of the proportion of younger employees turns to be insignificant again, the interaction terms are all insignificant 15

To summarize the results: Employees aged younger than 30 are significantly less productive than prime age workers. The negative raw effect of older workers (50 or older) becomes insignificant when control variables are considered in the estimations. There are no significant interactions between the proportion of older workers and the IT intensity of the firm. Thus, older workers do not lower IT-enabled productivity. The percentage share of older employees working predominately at a computer reveals a positive and significant relationship with labour productivity. IT intensity is positively and significantly related to labour productivity. The same holds for the application of incentive wages and - in most of the specifications - for units with profit and loss responsibility. Interaction terms between these variables, however, are all insignificant. Thus, complementarities between the age structure of employees, incentive wages or units with profit and loss responsibility and IT intensity do not seem to exist.

One might suspect that the proportion of older workers in a company is positively selected and thus endogenous (see for instance Aubert and Crépon, 2003). On the one hand, companies might part with older workers for instance by early retirement

\footnotetext{
${ }^{15}$ The regressions presented in Table 3 were also run with old pcwork as the variable taking account of the share of older workers working predominately at a PC. However, the results did not change qualitatively.
} 
programs. On the other hand, older employees might decide to leave the labour market if their workplaces are affected by technological change and if sufficient support by social security systems is available.

In order to account for that potential endogeneity problem, we firstly consider the development of the percentage shares of older and younger workers since 2001. Therefore, we use a third wave of our ICT survey conducted in 2002. As Table 5 in the appendix shows, the proportion of employees belonging to a certain age group varies only little over the considered time period on average. The proportion of employees being 50 years or older slightly increases from about 18 percent in 2001 to about 22 percent in 2006. The proportion of employees aged younger than 30 years decreases from about 29 to about 26 percent. These developments seem to reflect the natural aging process of the workforce rather than a systematic selection mechanism. Moreover, the kernel density estimations in Figures 1 and 2 in the appendix as well as a Kolmogorov-Smirnov test indicate that the distributions of the proportion of younger as well as of older workers do not differ significantly over the three years 2002, 2004 and 2007.

Secondly, we use an instrumental variables approach estimated by two stage least squares. Two variables serve as instruments for the proportion of employees being older than 49 years: the firm age and the existence of a collective labour agreement. Firm age seems to be highly correlated with the proportion of older workers in a firm since a firm's workforce ages over a firm's life time. On the other hand, one may assume that the firms' productivity is rather related to organisational and technological factors that are important for efficient business processes than to firm age. The existence of a collective labour agreement reflects the fact that firms applying such an agreement are more restricted with respect to job protection than others and thus might be more inflexible with respect to dismissing older workers. The results can be found in Table 6 in the appendix. The two instruments are positive and significant. A test on overidentifying restrictions does not hint to an overidentification (Score Chi $=1.17489, \mathrm{p}=0.2784$ ). In the productivity estimation the coefficient of the proportion of employees older than 49 is still negative and insignificant.

This result might reflect different aspects: First, we might not have found the perfect instrumental variables. One might think for instance of variables measuring the labour supply with respect to different age groups and regions. Therefore, we ran further regressions with the following two instrumental variables: the firm age and 
the proportion of the labour force aged between 30 and 50 within the total labour force according to different sectors and Bundesländer as a measure of the labour supply that could potentially replace the older workers. However, the impact of the proportion of older workers remains negative and insignificant. Moreover, the coefficient becomes quite large and imprecisely estimated (coefficient -1.685 , standard error: 1.408).

Second, our measure of the share of older workers might be too crude. However, due to data limitations we are not able to further differentiate within the age group older than 49. Another aspect is that in fact, during the last couple of years, it has become more difficult to leave the labour market at the age of 50 since on the one hand institutional support such as the unemployment compensation system has been cut back considerably; on the other hand, firms might depend on older workers since the labour force has been shrinking owing to the demographic development.

Third, in 2006, employees at the age of 50 on average had a more advanced educational background and had better computer skills than employees at the age of 50 in the eighties or nineties. Thus, the proportion of older workers might be 'less endogenous' than it was still a couple of years ago.

Finally, the study by Aubert and Crépon (2003) for instance discusses extensively the problems involved with consistently estimating the productivity effects of age groups within firms. Although these authors use a large French data set (between 19,000 and 29,000 observations) and apply various estimation methods (including OLS and GMM) and various kinds of standardising the variables (inter and intra firm variations) their results do not reveal that older workers are significantly less productive than prime age workers. By contrast, they find even positive and significant effects for the age groups 50 to 54 and 55 to 59 in the commerce sector and positive and significant impacts for the age group 50 to 54 in the service sector compared to the reference age group of 35 to 39 years old employees, while there is no significant effect in the manufacturing industry.

The exposition of these arguments demonstrates that there is still a lot to investigate in the course of future research. A further aspect not taken into account in this paper is unobserved heterogeneity. The estimations are based on information from two different waves of the data, however, some of the variables are contained in only one of the waves such that fixed effects estimation is not possible. 
Table 3: Estimation Results with Interaction Terms, OLS

\begin{tabular}{|c|c|c|c|c|}
\hline \multicolumn{5}{|c|}{ dependent variable: log labour productivity } \\
\hline Variable & $(5)$ & $(6)$ & (7) & $(8)$ \\
\hline share of empl. below 30 years & $\begin{array}{l}-0.308 \\
(0.200)\end{array}$ & $\begin{array}{l}-0.375^{*} \\
(0.192)\end{array}$ & $\begin{array}{c}-0.381^{* * *} \\
(0.123)\end{array}$ & $\begin{array}{l}-0.281 \\
(0.244)\end{array}$ \\
\hline share of empl. above 49 years & $\begin{array}{l}-0.195 \\
(0.262)\end{array}$ & $\begin{array}{c}-0.020 \\
(0.223)\end{array}$ & $\begin{array}{l}-0.077 \\
(0.162)\end{array}$ & $\begin{array}{l}-0.110 \\
(0.283)\end{array}$ \\
\hline $\log$ (employment) & $\begin{array}{c}-0.106^{* * *} \\
(0.025)\end{array}$ & $\begin{array}{c}-0.104^{* * *} \\
(0.025)\end{array}$ & $\begin{array}{c}-0.105^{* * *} \\
(0.025)\end{array}$ & $\begin{array}{c}-0.105^{* * *} \\
(0.025)\end{array}$ \\
\hline $\log$ (gross investment) & $\begin{array}{c}0.133^{* * *} \\
(0.019)\end{array}$ & $\begin{array}{c}0.133^{* * *} \\
(0.019)\end{array}$ & $\begin{array}{c}0.133^{* * *} \\
(0.019)\end{array}$ & $\begin{array}{c}0.133^{* * *} \\
(0.019)\end{array}$ \\
\hline share of high-skilled empl. & $\begin{array}{c}0.507^{* * *} \\
(0.162)\end{array}$ & $\begin{array}{c}0.492^{* * *} \\
(0.163)\end{array}$ & $\begin{array}{c}0.500^{* * *} \\
(0.163)\end{array}$ & $\begin{array}{c}0.497^{* * *} \\
(0.165)\end{array}$ \\
\hline share of medium-skilled empl. & $\begin{array}{c}0.351^{* * *} \\
(0.117)\end{array}$ & $\begin{array}{c}0.351^{* * *} \\
(0.118)\end{array}$ & $\begin{array}{c}0.354^{* * *} \\
(0.118)\end{array}$ & $\begin{array}{c}0.347^{* * *} \\
(0.118)\end{array}$ \\
\hline pcwork & $\begin{array}{l}0.425^{* *} \\
(0.171)\end{array}$ & $\begin{array}{c}0.450^{* * *} \\
(0.100)\end{array}$ & $\begin{array}{c}0.443^{* * *} \\
(0.133)\end{array}$ & $\begin{array}{l}0.430^{* *} \\
(0.206)\end{array}$ \\
\hline incentive wages & $\begin{array}{c}0.126^{* * *} \\
(0.044)\end{array}$ & $\begin{array}{c}0.192^{*} \\
(0.107)\end{array}$ & $\begin{array}{l}0.129^{*} \\
(0.072)\end{array}$ & $\begin{array}{c}0.201 \\
(0.128)\end{array}$ \\
\hline units with P\&L responsibility & $\begin{array}{l}0.108^{* *} \\
(0.049)\end{array}$ & $\begin{array}{c}0.065 \\
(0.118)\end{array}$ & $\begin{array}{c}0.084 \\
(0.082)\end{array}$ & $\begin{array}{c}0.038 \\
(0.153)\end{array}$ \\
\hline exporting activities & $\begin{array}{l}0.101^{* *} \\
(0.475)\end{array}$ & $\begin{array}{l}0.100^{* *} \\
(0.047)\end{array}$ & $\begin{array}{l}0.102^{* *} \\
(0.048)\end{array}$ & $\begin{array}{l}0.101^{* *} \\
(0.047)\end{array}$ \\
\hline below 30 years* pcwork & $\begin{array}{c}-0.143 \\
(0.354)\end{array}$ & & & $\begin{array}{l}-0.207 \\
(0.358)\end{array}$ \\
\hline above 49 years* pcwork & $\begin{array}{c}0.263 \\
(0.467)\end{array}$ & & & $\begin{array}{c}0.280 \\
(0.460)\end{array}$ \\
\hline incentive wages*pcwork & & & $\begin{array}{l}-0.012 \\
(0.140)\end{array}$ & $\begin{array}{l}-0.015 \\
(0.142)\end{array}$ \\
\hline units with P\&L responsibility*pcwork & & & $\begin{array}{c}0.049 \\
(0.153)\end{array}$ & $\begin{array}{c}0.047 \\
(0.163)\end{array}$ \\
\hline below 30 years*incentive wages & & $\begin{array}{c}-0.124 \\
(0.242)\end{array}$ & & $\begin{array}{l}-0.130 \\
(0.242)\end{array}$ \\
\hline above 49 years*incentive wage & & $\begin{array}{c}-0.181 \\
(0.339)\end{array}$ & & $\begin{array}{l}-0.171 \\
(0.340)\end{array}$ \\
\hline $\begin{array}{l}\text { below } 30 \text { years* units with } \mathrm{P} \& \mathrm{~L} \\
\text { responsibility }\end{array}$ & & $\begin{array}{c}0.215 \\
(0.294)\end{array}$ & & $\begin{array}{c}0.247 \\
(0.301)\end{array}$ \\
\hline $\begin{array}{l}\text { above } 49 \text { years* units with P\&L } \\
\text { responsibility }\end{array}$ & & $\begin{array}{l}-0.065 \\
(0.426)\end{array}$ & & $\begin{array}{l}-0.081 \\
(0.439)\end{array}$ \\
\hline dummies for sectors and region & yes & yes & yes & yes \\
\hline Number of observations & 808 & 808 & 808 & 808 \\
\hline $\mathrm{R}^{2}$ & 0.366 & 0.366 & 0.365 & 0.367 \\
\hline F statistic & 18.98 & 17.57 & 19.14 & 15.43 \\
\hline
\end{tabular}

Significance levels : $\quad *: 10 \% \quad * *: 5 \% \quad * * *: 1 \%$;

heteroscedasticity-robust standard errors 


\section{Conclusions}

The attempt of the paper was to provide empirical evidence on the question whether firms' IT-enabled productivity is lowered by older workers. The theoretical considerations are based on a simple production function framework with heterogenous labour quality. Using firm-level data from German manufacturing and services industries econometric estimations reveal that workers older than 49 are not significantly less productive than prime age workers. Older workers using a computer are more productive than older non-computer users. Interactions between IT intensity and the proportion of older workers show no significant effects, thus, older workers do not lower IT-enabled productivity.

The results reveal that positive productivity effects owing to computer usage at the workplace are not restricted to certain age groups but do also exist for the case of older workers. Moreover, an ageing workforce and technological progress are not necessarily conflicting trends. An efficient allocation of resources combined with measures of lifelong learning may help to reap the potentials inherent in new technologies. Furthermore, it might allow to keep older workers actively in the labour market. Amongst other measures, this could form a solution to future skill shortage due to a shrinking labour force and a depreciation of technological knowledge.

Further research could go in various directions: Firstly, alternative econometric techniques could be applied taking account of endogeneity of the input factors or unobserved heterogeneity. The general method of moments (GMM) as applied for instance by Hempell (2005) or the method by Olley and Pakes (1996) are potential candidates. However, both techniques need panel data with a longer time horizon. Secondly, a different approach is the frontier production framework allowing to analyse a firm's distance from the technological frontier (see for instance Kumbakhar and Lovell, 2000). It might be interesting to investigate the impact of an ageing workforce on this distance. Thirdly, more detailed information about the ICT applications used by older workers as well as on the task composition of older workers compared to those of their younger counterparts could help to shed more light on the relationship between ICT and the age structure of the workforce and its implications for firm performance. For example, new applications like blogs or wikis for supporting the knowledge management of firms might constitute appropriate tools to combine the experience of older employees and the skills of younger ones in order to increase firms' productivity and innovation capability. 


\section{References}

Aliaga, C. and Romans, F. (2006). Die Erwerbstätigkeit älterer Menschen in der Europäischen Union, Statistik kurz gefasst 15.

Aubert, P., Caroli, E. and Roger, M. (2006). New technologies, organisation and age: Firm-level evidence, The Economic Journal 116: F73-F93.

Aubert, P. and Crépon, B. (2003). La productivité des salariés agés: une tentative d'estimation, Économie et Statistique 368: 95-119.

Autor, D. H., Levy, F. and Murnane, R. J. (2003). The skill content of recent technological change: An empirical exploration, Quarterly Journal of Economics 118(4): 1279-1333.

Bartel, A. P. and Sichermann, N. (1993). Technological change and retirement decisions of older workers, Journal of Labour Economics 11(1): 162-183.

Beckmann, M. (2001). Die Auswirkungen des betrieblichen Personalabbaus auf die Altersstruktur der Belegschaften in westdeutschen Unternehmen, in U. BackesGellner, M. Krakel, D. Sadowski and J. Mure (eds), Entlohnung, Arbeitsorganisation und personalpolitische Regulierung, München und Mering, pp. 217-242.

Bernard, A. B. and Jensen, J. B. (2004). Exporting and productivity in the USA, Oxford Review of Economic Policy 20(3): 343-357.

Bertschek, I. (2003). Information technology and productivity gains and cost savings in companies, in D. C. Jones (ed.), New Economy Handbook, Elsevier Science, Amsterdam, pp. 213-228.

Bertschek, I. (2004). Führt IT-Nutzung zu altersfeindlicher Reorganisation von Arbeit? Eine Untersuchung auf Grundlage des ZEW, in B. Fitzenberger, W. Smolny and P. Winker (eds), Herausforderungen an den Wirtschaftsstandort Deutschland, Vol. 72 of ZEW Wirtschaftsanalysen, Nomos, Baden-Baden, pp. 249-263.

Bertschek, I. and Kaiser, U. (2004). Productivity effects of organisational change: Microeconometric evidence, Management Science 50(3): 394-404.

Black, S. E. and Lynch, L. M. (2001). How to compete: The impact of workplace practices and information technology on productivity, The Review of Economics and Statistics 83(3): 434-445.

Boockmann, B. and Zwick, T. (2004). Betriebliche Determinanten der Beschäftigung älterer Arbeitnehmer, Zeitschrift für Arbeitsmarktforschung 1: 53-63. 
Borghans, L. and ter Weel, B. (2002). Do older workers have more trouble using a computer than younger workers?, Research memorandum, MERIT and International Institute of Infonomics.

Börsch-Supan, A., Düzgün, I. and Weiss, M. (2005). Altern und Produktivität: Zum Stand der Forschung, Discussion Paper 73-05, MEA.

Bresnahan, T. F., Brynjolfsson, E. and Hitt, L. M. (2002). Information technology, workplace organization and the demand for skilled labor: Firm-level evidence, The Quarterly Journal of Economics 117(1): 339-376.

Bresnahan, T. F. and Trajtenberg, M. (1995). General purpose technologies: Engines of growth, Journal of Econometrics 65: 83-108.

Brynjolfsson, E. and Hitt, L. (2000). Beyond computation: Information technology, organizational transformation and business performance, Journal of Economic Perspectives 14(4): 23-48.

Card, D. and DiNardo, J. E. (2002). Skill-biased technological change and rising wage inequality: Some problems and puzzles, Journal of Labor Economics 20(4): 733-783.

Chennells, L. and van Reenen, J. (2002). Technical change and the structure of employment and wages: A survey of the microeconometric evidence, in N. Greenan, Y. L'Horty and J. Mairesse (eds), Productivity, Inequality and the Digital Economy, MIT Press, Cambridge, MA, pp. 175-223.

Crépon, B., Deniau, N. and Pérez-Duarte, S. (2002). Wages, productivity, and workers characteristics: A French perspective. mimeo, Centre de Recherche en Économie et Statistique (CREST) and Institut National de la Statistique et des Études Économiques (INSEE), Paris.

Draca, M., Sadun, R. and van Reenen, J. (2007). Productivity and ICTs: A review of the evidence, in R. Mansell, C. Avgerau, D. Quah and R. Silverstone (eds), The Oxford Handbook of Information and Communication Technologies, Oxford University Press, pp. 100-147.

Friedberg, L. (2003). The impact of technological change on older workers: Evidence from data on computer use, Industrial and Labor Relations Review 56(3): 511529 .

Griffith, R., Huergo, E., Mairesse, J. and Peters, B. (2006). Innovation and productivity across four european countries, Oxford Review of Economic Policy 22(4): 483-498. 
Grund, C. and Westergard-Nielsen, N. (2005). Age structure of the workforce and firm performance, Discussion Paper 1816, IZA Institute for the Study of Labor, Bonn.

Haltiwanger, J., Lane, J. I. and Spletzer, J. R. (1999). Productivity differences across employers: The roles of employer size, age, and human capital, AER Paper and Proceedings 89(2): 94-98.

Hellerstein, J. K., Neumark, D. and Troske, K. R. (1999). Wages, productivity, and worker characteristics: Evidence from plant-level production functions and wage equations, Journal of Labor Economics 17(3): 409-446.

Hempell, T. (2005). What's spurious? what's real? measuring the productivity impacts of ict at the firm level, Empirical Economics 30(2): 427-464.

Hirsch, B. T., MacPherson, D. A. and Hardy, M. A. (2000). Occupational age structure and access for older workers, Industrial and Labor Relations Review 53(3): 401-418.

Ilmakunnas, P., Maliranta, M. and Vainiomki, J. (2004). The roles of employer and employee characteristics for plant productivity, Journal of Productivity Analysis 21(3): 249-276.

Kumbakhar, S. and Lovell, C. (2000). Stochastic Frontier Analysis, Cambridge University Press, Cambridge (Mass.).

Lisbon European Council (2000). Presidency conclusions.

Olley, G. S. and Pakes, A. (1996). The dynamics of productivity in the telecommunications equipment, Econometrica 64(6): 1263-1297.

Prskawetz, A., Mahlberg, B., Skirbekk, V., Freund, I., Winkler-Dworak, M., Lindh, T., Malmberg, B., Jans, A.-C., Nordström, O. S. and Andersson, F. (2006). The impact of population ageing on innovation and productivity growth in Europe - Research Report 28, Research Report 28, Vienna Institute of Demography, Vienna, Austria.

Schleife, K. (2006). Computer use and the employment status of older workers - an analysis based on individual data, LABOUR: Review of Labour Economics and Industrial Relations 20(2): 325-348.

Schneider, L. (2007). Sind ältere Beschäftigte weniger produktiv? Eine empirische Analyse anhand des LIAB, Zeitschrift für Arbeitsmarktforschung 40(1): 77-98. 
Skirbekk, V. (2004). Age and individual productivity: A literature survey, in G. Feichtinger (ed.), Vienna Yearbook of Population Research, Vienna.

Spitz-Oener, A. (2006). Technical change, job tasks and rising educational demands: Looking outside the wage structure, Journal of Labor Economics 24(2): 235270 .

Statistisches Bundesamt (2007). IKT in Unternehmen, Nutzung von Informationstechnologie in Unternehmen, Ergebnisse für das Jahr 2006, Statistisches Bundesamt, Wiesbaden.

Weinberg, B. A. (2004). Experience and technology adoption, Discussion Paper 1051, IZA Institute for the Study of Labor, Bonn. 


\section{A Appendix}

Table 4: Distribution of Firms Across Industries in the Samples

\begin{tabular}{lcccc}
\hline \hline & \multicolumn{3}{c}{ large sample } & \multicolumn{2}{c}{ small sample } \\
\hline Industry & Obs. & Perc. & Obs. & Perc. \\
\hline consumer goods & 92 & 8.85 & 71 & 9.15 \\
chemical industry & 56 & 5.39 & 40 & 5.15 \\
other raw materials & 82 & 7.89 & 63 & 8.12 \\
metal and machine construction & 126 & 12.13 & 95 & 12.24 \\
electrical engineering & 75 & 7.22 & 53 & 6.83 \\
precision instruments & 86 & 8.28 & 68 & 8.76 \\
automobile & 62 & 5.97 & 34 & 4.38 \\
wholesale trade & 45 & 4.33 & 34 & 4.38 \\
retail trade & 71 & 6.83 & 46 & 5.93 \\
transportation and postal services & 61 & 5.87 & 42 & 5.41 \\
banks and insurances & 39 & 3.75 & 31 & 3.99 \\
electronic processing and telecommunication & 86 & 8.28 & 66 & 8.51 \\
technical services & 89 & 8.57 & 70 & 9.02 \\
other business-related services & 69 & 6.64 & 53 & 6.83 \\
\hline sum & 1039 & 100 & 776 & 100 \\
\hline \hline
\end{tabular}

Source: ZEW ICT survey 2007, own calculations.

Table 5: Development of Percentage Shares of Age Groups

\begin{tabular}{llccccc}
\hline \hline Year & Variable & Obs & Mean & Std. Dev. & Min. & Max. \\
\hline \multirow{2}{2}{001} & share of empl. below 30 years & 3824 & 0.290 & 0.196 & 0 & 1 \\
& share of empl. above 49 years & 3858 & 0.181 & 0.147 & 0 & 1 \\
\hline \multirow{2}{*}{003} & share of empl. below 30 years & 3373 & 0.273 & 0.188 & 0 & 1 \\
& share of empl. above 49 years & 3713 & 0.191 & 0.156 & 0 & 1 \\
\hline \multirow{2}{2}{2006} & share of empl. below 30 years & 3718 & 0.263 & 0.186 & 0 & 1 \\
& share of empl. above 49 years & 3744 & 0.219 & 0.166 & 0 & 1 \\
\hline
\end{tabular}

Source: ZEW ICT surveys 2002, 2004, 2007. 
Figure 1: Kernel Density Estimation: Share of Employees Below 30 Years

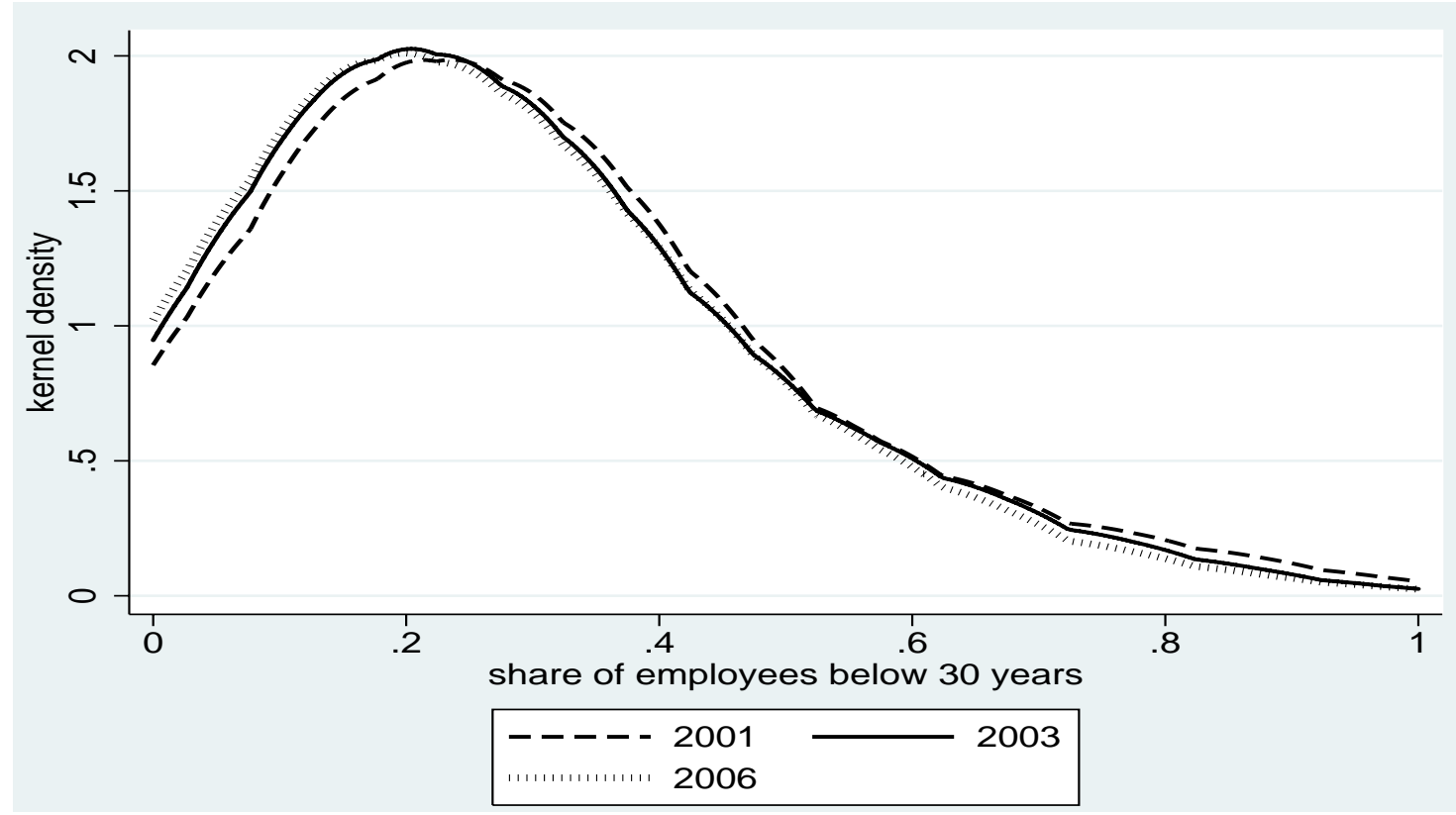

Source: ZEW ICT surveys 2002, 2004, 2007; bandwidth=0.1

Figure 2: Kernel Density Estimation: Share of Employees Above 49 Years

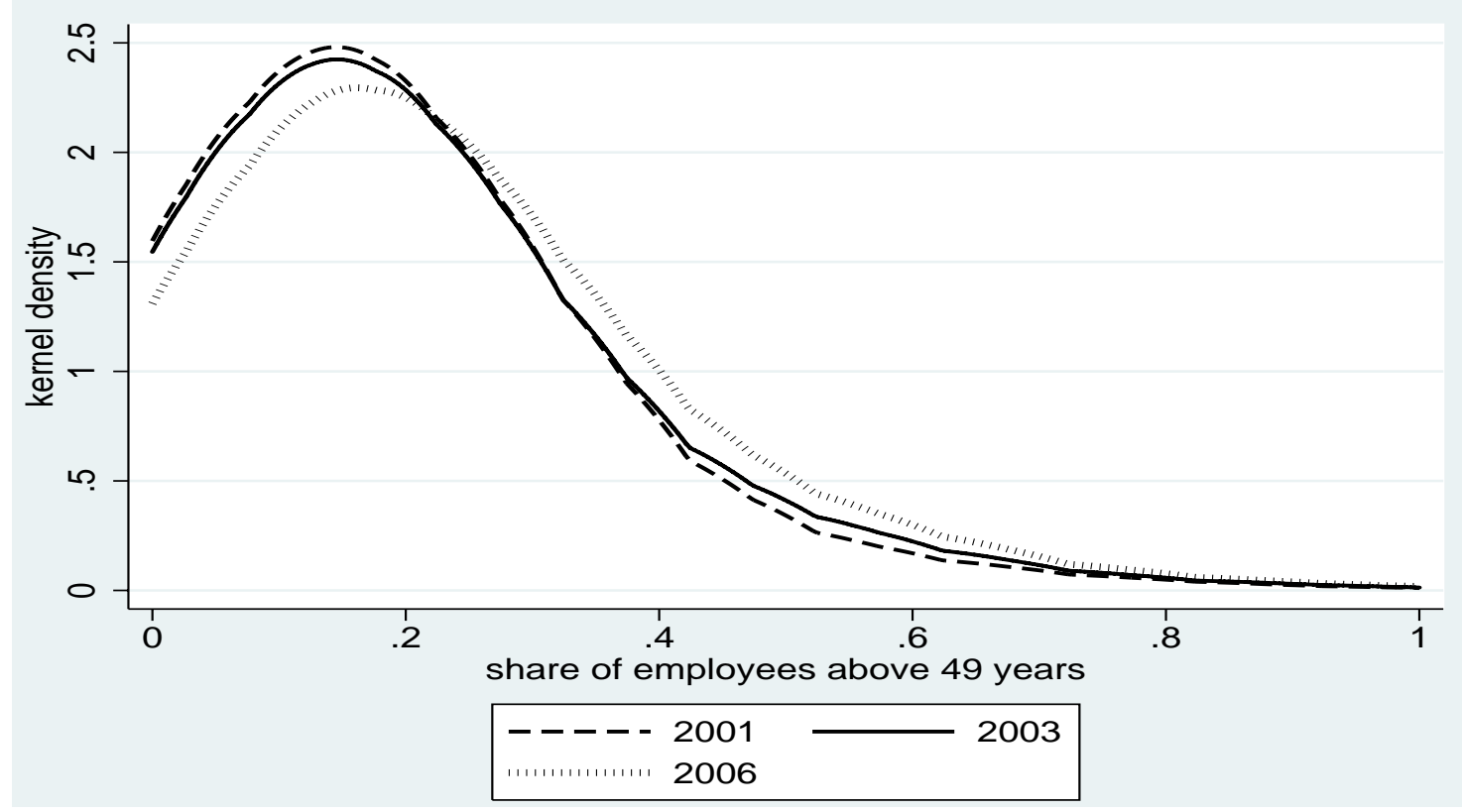

Source: ZEW ICT surveys 2002, 2004, 2007; bandwidth=0.1 
Table 6: Estimation Results IV-Estimation

\begin{tabular}{|c|c|c|}
\hline & \multicolumn{2}{|c|}{ / dependent variable } \\
\hline & share of older empl. & log labour prod. \\
\hline Variables & First Stage & IV (2SLS) \\
\hline firm age & $\begin{array}{l}0.0006^{* *} \\
(0.0003)\end{array}$ & \\
\hline collective labour & $0.035^{* * *}$ & \\
\hline agreement & $(0.011)$ & \\
\hline share of employees & & -0.428 \\
\hline above 49 years & & $(-0.998)$ \\
\hline share of employees & $-0.216^{* * *}$ & $-0.445^{*}$ \\
\hline below 30 years & $(0.029)$ & $(0.247)$ \\
\hline $\log$ (employment) & $\begin{array}{c}-0.009^{* *} \\
(0.006)\end{array}$ & $\begin{array}{c}-.109^{* * *} \\
(0.024)\end{array}$ \\
\hline log (gross investment) & $\begin{array}{c}0.004 \\
(0.004)\end{array}$ & $\begin{array}{c}0.137^{* * *} \\
(0.019)\end{array}$ \\
\hline share of high-skilled employees & $\begin{array}{c}-0.011 \\
0.040\end{array}$ & $\begin{array}{c}0.517^{* * *} \\
0.163\end{array}$ \\
\hline share of medium-skilled employees & $\begin{array}{l}-0.000 \\
(0.028)\end{array}$ & $\begin{array}{c}0.352^{* * *} \\
(0.115)\end{array}$ \\
\hline pcwork & $\begin{array}{l}-0.031 \\
(0.025)\end{array}$ & $\begin{array}{c}0.433^{* * *} \\
(0.110)\end{array}$ \\
\hline incentive wages & $\begin{array}{l}-0.013 \\
(0.011)\end{array}$ & $\begin{array}{c}0.122^{* * *} \\
(0.046)\end{array}$ \\
\hline units with $\mathrm{P} \& \mathrm{~L}$ responsibility & $\begin{array}{l}-0.000 \\
(0.010)\end{array}$ & $\begin{array}{l}0.105^{* *} \\
(0.048)\end{array}$ \\
\hline exporting activities & $\begin{array}{l}-0.020 \\
(0.012)\end{array}$ & $\begin{array}{l}0.087^{* *} \\
(0.051)\end{array}$ \\
\hline dummies for sectors and region & yes & yes \\
\hline Number of observations & 800 & 800 \\
\hline $\mathrm{R}^{2}$ & 0.1666 & 0.3576 \\
\hline test on overidentifying restrictions: & core $\operatorname{chi} 2(1)=1.174$ & $(\mathrm{p}=0.2784)$ \\
\hline
\end{tabular}

